\title{
Development and characterization of new microsatellites for Eugenia dysenterica DC (Myrtaceae)
}

M.P.C. Telles ${ }^{1}$, J.B. Silva ${ }^{1}$, L.V. Resende ${ }^{1}$, R.P. Vianello ${ }^{2}$, L.J. Chaves ${ }^{3}$, T.N. Soares ${ }^{1}$ and R.G. Collevatti ${ }^{1}$

${ }^{1}$ Laboratório de Genética \& Biodiversidade, Instituto de Ciências Biológicas, Universidade Federal de Goiás, Goiânia, GO, Brasil

${ }^{2}$ Laboratório de Biotecnologia,

Empresa Brasileira de Pesquisa Agropecuária Arroz e Feijão, Santo Antônio de Goiás, GO, Brasil

${ }^{3}$ Escola de Agronomia, Universidade Federal de Goiás,

Goiânia, GO, Brasil

Corresponding author: M.P.C. Telles

E-mail: tellesmpc@gmail.com

Genet. Mol. Res. 12 (3): 3124-3127 (2013)

Received May 31, 2012

Accepted July 31, 2012

Published February 6, 2013

DOI http://dx.doi.org/10.4238/2013.February.6.3

\begin{abstract}
Microsatellite markers were developed for population genetic analyses of the Neotropical tree Eugenia dysenterica DC (Myrtaceae), after construction of a shotgun genomic library for microsatellite discovery. Nine primers were designed, of which 5 yielded amplified product. These primers were polymorphic for 97 individuals collected in 3 distinct localities. The number of alleles per locus (primer) ranged from 3 to 11 and expected heterozygosities varied from 0.309 to 0.884 . The probability of locus identity was $\sim 1.88$ x $10^{-4}$ and the probability of paternity exclusion was $\sim 0.9367$. The 5 microsatellite primer pairs may be suitable for population genetic studies such as parentage and fine-scale genetic analyses of this species.
\end{abstract}

Key words: Cagaita; Cerrado; Genetic diversity; Shotgun library; Microsatellite 


\section{INTRODUCTION}

Eugenia dysenterica (Myrtaceae) is a Neotropical tree widely distributed in the Brazilian savannas of the Cerrado Biome, Central Brazil. The fruit is enjoyed for the edible and refreshing mesocarp that is consumed in natura or as a source of raw material for small and middle-sized food industries, and plays an important role in the local economy of Central Brazil (Sano et al., 1995). Previous population genetic studies using different molecular markers indicated low genetic diversity and high differentiation among populations of $E$. dysenterica (Telles et al., 2003; Zucchi et al., 2005). However, despite its high ecological and economic importance, the only 7 polymorphic microsatellites available for this species were transferred from Eucalyptus (Zucchi et al., 2002). Thus, the development of more specific molecular markers is important to clarify the evolutionary mechanisms of genetic variability in this species.

This study is part of a larger project to characterize genetic variability and evaluate ecological and evolutionary processes in Cerrado tree species, and the development and characterization of microsatellite loci is an important step toward this goal (see Telles et al., 2011; Soares et al., 2012). Here we report the development and characterization of microsatellite loci for $E$. dysenterica and demonstrate their suitability for further studies in population genetic structure and gene flow.

\section{MATERIAL AND METHODS}

We developed a genomic shotgun library for microsatellite isolation and primer design. DNA from an individual E. dysenterica was extracted by the $2 \%$ CTAB protocol (Doyle and Doyle, 1987) and sheared $(2.0 \mu \mathrm{g})$ using a sonicator at $120 \mathrm{~W}$ for $1 \mathrm{~h}$ and $45 \mathrm{~min}$. Fragments from $200 \mathrm{bp}$ to $1.0 \mathrm{~kb}$ were recovered, cloned into dephosphorylated pMOSBlue blunt vector using the Blunt-ended PCR Cloning $\mathrm{Kit}^{\mathbb{B}}$ (GE HealthCare, Uppsala, Sweden), and sequenced on an Applied Biosystems 3100 automated DNA sequencer (Applied Biosystems, Foster City, CA, USA). For sequencing, we used the U19 primer with the DYEnamicET terminator kit (GE Healthcare), according to manufacturer instructions. Sequences were screened for microsatellites using the WEBSAT software (Martins et al., 2009) and primers were designed using Primer3 (Rozen and Skaletsky, 2000). The following stringent criteria were applied for primer design: i) maximum primer Tm (melting temperature) $68^{\circ} \mathrm{C}$; ii) maximum $3^{\circ} \mathrm{C}$ difference in $\mathrm{Tm}$ between primers; iii) GC content ranging from 40 to $60 \%$; iv) maximum of 2 dimers between primers; v) absence of hairpins.

We then genotyped 97 individuals from 3 localities (local populations) widely scattered throughout the species' geographic range, Balneário Santo Antonio (S15 $59.52^{\prime}$, W50 ${ }^{\circ}$ $\left.6.695^{\prime}\right)$ in Goiás State, Roda Velha (S12 $\left.58.343^{\prime}, \mathrm{W}^{\circ} 5^{\circ} 59.392^{\prime}\right)$ in Bahia State, and Porto Nacional (S10 42.892', W48 46.840') in Tocantins State.

Genotyping was performed in a $15-\mu \mathrm{L}$ reaction volume containing $15 \mathrm{ng}$ template DNA, $2.60 \mu \mathrm{M}$ of each primer, $1 \mathrm{U}$ Taq DNA polymerase (Phoneutria, Brazil), $210 \mu \mathrm{M}$ of each dNTP, $2.16 \mathrm{mg}$ bovine serum albumin, and $1 \mathrm{X}$ reaction buffer $(10 \mathrm{~mm}$ Tris- $\mathrm{HCl}, \mathrm{pH} 8.3,50 \mathrm{~mm} \mathrm{KCl}$, $1.5 \mathrm{~mm} \mathrm{MgCl} 2)$, with the following conditions: $95^{\circ} \mathrm{C}$ for $5 \min (1 \mathrm{cycle}) ; 94^{\circ} \mathrm{C}$ for $1 \mathrm{~min}, 52^{\circ}$ to $64^{\circ} \mathrm{C}$ (see Table 1 ) for $1 \mathrm{~min}, 72^{\circ} \mathrm{C}$ for $1 \mathrm{~min}\left(30\right.$ cycles); $72^{\circ} \mathrm{C}$ for $7 \mathrm{~min}$ ( 1 cycle). PCR fragments were electrophoresed on $6 \%$ denaturing polyacrylamide gels stained with silver nitrate (Creste et al., 2001) and sized by comparison to a 10-bp DNA ladder (Invitrogen). 


\section{RESULTS}

We sequenced 1632 clones from the genomic library and 713 cloned inserts contained microsatellites. Of these, 683 were mononucleotide (95.79\%), 25 dinucleotide (3.51\%), 2 trinucleotide $(0.28 \%)$, and 3 tetranucleotide $(0.42 \%)$. However, primers could be designed for only 9 microsatellite loci and 5 of these amplified clearly interpretable products in a single PCR protocol (Table 1).

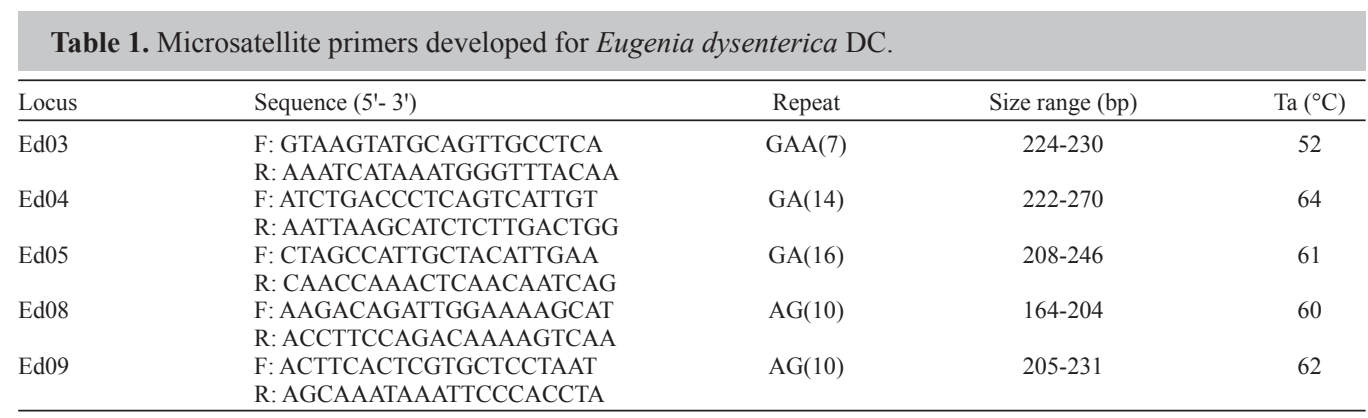

Data reported for 97 individuals from three local populations. $\mathrm{Ta}=$ annealing temperature.

E. dysenterica presented similar levels of polymorphism as other plant species from the Brazilian Cerrado (e.g., Telles et al., 2011; Soares et al., 2012), with 3 to 11 alleles per locus and expected heterozygosities ranging from 0.309 to 0.884 (Table 2). The polymorphism level was also similar to the one obtained using microsatellites transferred from Eucalyptus (Zucchi et al., 2002). All pairs of loci were in linkage equilibrium $(\mathrm{P}>0.05)$, when analyses were performed with the FSTAT 2.9.3.2 software (Goudet, 2002). The 5 loci presented relatively low probability of identity for all local populations $\left(1.8752 \times 10^{-4}\right)$ and high $(0.936650404)$ probability of paternity exclusion.

Table 2. Genetic characterization of five microsatellite loci in three populations of Eugenia dysenterica DC.

\begin{tabular}{|c|c|c|c|c|c|c|c|c|c|c|c|c|}
\hline \multirow[t]{2}{*}{ Locus } & \multicolumn{4}{|c|}{ BSAGO local population } & \multicolumn{4}{|c|}{ RVBA local population } & \multicolumn{4}{|c|}{ PNTO local population } \\
\hline & $\mathrm{N}$ & $N_{A}$ & $H_{\mathrm{E}}$ & $H_{\mathrm{O}}$ & $\mathrm{N}$ & $N_{A}$ & $H_{\mathrm{E}}$ & $H_{\mathrm{o}}$ & $\mathrm{N}$ & $N_{A}$ & $H_{\mathrm{E}}$ & $H_{\mathrm{O}}$ \\
\hline Ed03 & 32 & 3 & 0.309 & 0.094 & 32 & 3 & 0.678 & 0.344 & 33 & 3 & 0.600 & 0.212 \\
\hline Ed04 & 32 & 8 & 0.483 & 0.406 & 32 & 8 & 0.437 & 0.000 & 33 & 11 & 0.511 & 0.296 \\
\hline Ed05 & 32 & 7 & 0.714 & 0.313 & 32 & 7 & 0.557 & 0.485 & 33 & 10 & 0.884 & 0.697 \\
\hline Ed08 & 32 & 4 & 0.830 & 0.406 & 32 & 6 & 0.769 & 0.812 & 33 & 6 & 0.835 & 0.787 \\
\hline Ed09 & 32 & 4 & 0.682 & 0.625 & 32 & 6 & 0.807 & 0.682 & 33 & 7 & 0.794 & 0.666 \\
\hline
\end{tabular}

$\mathrm{BSAGO}=$ Balneário Santo Antonio; RVBA $=$ Roda Velha; PNTO $=$ Porto Nacional. $\mathrm{N}=$ number of individuals genotyped; $N_{A}=$ number of alleles; $H_{\mathrm{E}}=$ expected heterozygosity; $H_{\mathrm{O}}=$ observed heterozygosity.

Thus, the 5 microsatellite loci developed in this study may be suitable for parentage analysis and fine-scale genetic structure and present a new opportunity for the generation of genetic data for E. dysenterica. 


\section{ACKNOWLEDGMENTS}

Research supported by CNPq (Proc. \#475182/2009-0 and \#563839/2010-4), FAPEG/ AUX PESQ CH 007/2009, and Systema Naturae Consultoria Ambiental Ltda. The research of M.P.C. Telles, R.G. Collevatti and T.N. Soares in Molecular Ecology has been continuously supported by $\mathrm{CNPq}$ and CAPES grants and fellowships.

\section{REFERENCES}

Creste S, Tulmann Neto A and Figueira A (2001). Detection of single sequence repeat polymorphisms in denaturing polyacrylamide sequencing gels by silver staining. Plant Mol. Biol. Rep. 19: 299-306.

Doyle JJ and Doyle JL (1987). Isolation of plant DNA from fresh tissue. Focus 12: 13-15.

Goudet J (2002). FSTAT 2.9.3.2.: A Program to Estimate and Test Gene Diversities and Fixation Indices. Available at [http://www.unil.ch/izea/softwares/fstat.html]. Accessed March 5, 2012.

Martins WS, Lucas DC, Neves KF and Bertioli DJ (2009). WebSat - a web software for microsatellite marker development. Bioinformation 3: 282-283.

Rozen S and Skaletsky HJ (2000). Primer3 on the WWW for General Users and for Biologist Programmers. In: Bioinformatics Methods and Protocols: Methods in Molecular Biology (Krawetz S and Misener S, eds.). Humana Press, Totowa, 365-386.

Sano SM, Fonseca CEL, Ribeiro JF, Oga FM, et al. (1995). Folhação, floração, frutificação e crescimento inicial da cagaiteira em Planaltina. Pesq. Agropec. Bras. 30: 5-14.

Soares TN, Melo DB, Resende LV, Vianello RP, et al. (2012). Development of microsatellite markers for the neotropical tree species Dipteryx alata (Fabaceae). Am. J. Bot. 99: e72-e73.

Telles MPC, Coelho ASG, Chaves LJ, Diniz-Filho JAF, et al. (2003). Genetic diversity and population structure of Eugenia dysenterica DC. ("cagaiteira" - Myrtaceae) in Central Brazil: Spatial analysis and implications for conservation and management. Conserv. Genet. 4: 685-695.

Telles MP, Peixoto FP, Lima JS, Resende LV, et al. (2011). Development of microsatellite markers for the endangered Neotropical tree species Tibouchina papyrus (Melastomataceae). Genet. Mol. Res. 10: 321-325.

Zucchi MI, Brondani RPV, Pinheiro JB, Brondani C, et al. (2002). Transferability of microsatellite markers from Eucalyptus spp. to Eugenia dysenterica (Myrtaceae family). Mol. Ecol. Notes 2: 512-513.

Zucchi MI, Pinheiro JB, Chaves LJ, Coelho ASG, et al. (2005). Genetic structure and gene flow of Eugenia dysenterica natural populations. Pesq. Agropec. Bras. 40: 975-980. 